\title{
INVESTIGATING ANCIENT MAYA AGRICULTURAL ADAPTATION THROUGH GROUND PENETRATING RADAR (GPR) ANALYSIS OF KARST TERRAIN, NORTHERN YUCATÁN, MEXICO
}

\author{
UPORABA GEORADARJA PRI RAZISKAVAH PRILAGODITEV \\ MAJEVSKEGA KMETIJSTVA NA KRAŠKEM POVRŠJU \\ SEVERNEGA JUKATANA, MEHIKA
}

\author{
Mandy J. MUNRO-STASIUK ${ }^{1} \&$ T. Kam MANAHAN ${ }^{2}$
}

\begin{abstract}
s
UDC $930.85(726.6)$

551.435.8:528.9

Mandy J. Munro-Stasiuk \& T. Kam Manahan: Investigating Ancient Maya Agricultural Adaptation through Ground Penetrating Radar (GPR) Analysis of Karst Terrain, Northern Yucatán, Mexico

Landscape adaptation on the Northern Yucatán Peninsula, Mexico, is particularly difficult, as soils are thin and the terrain is devoid of any surface water other than the occasional sinkhole (cenote) that connects directly to the groundwater system. Despite this, ancient Maya cities, including Xuenkal, emerged and thrived, likely because of their proximity to natural sinkholes. In the case of Xuenkal, these sinkholes, known locally as rejolladas, have bases above the local water table and, as such, do not provide direct access to the underlying water, but they provide closer access. Recognizing that the presence of rejolladas was likely important to the ancient Maya the purpose of this study is to characterize the rejolladas in terms of their subsurface characteristics, specifically bedrock configuration and soil. Ground penetrating radar analysis, as well as the results of a test pit excavation, confirm the presence of deep soils in the rejollada bases. It seems that the smaller deeper rejolladas have the thickest soils and sediment. The ancient city of Xuenkal is constructed amidst a particularly dense cluster of rejolladas which may have contributed to its location. Rejolladas, containing significantly thicker soils than the surrounding karst surface, and the ability to sustain dense healthy vegetation would have been particularly desirable for the Maya to capitalize on. Keywords: rejollada, sinkhole, archaeology, satellite imagery, ground penetrating radar.
\end{abstract}

Izvlečel

UDK 930.85(726.6)

551.435.8:528.9

Mandy J. Munro-Stasiuk \& T. Kam Manahan: Uporaba georadarja pri raziskavah prilagoditev majevskega kmetijstva na kraškem površju severnega Jukatana, Mehika

Prilagoditev življenja na kraškem površju severnega dela polotoka Jukatan v Mehiki, je bilo izjemno težko. Prsti je malo, voda pa je dostopna edino $\mathrm{v}$ udornicah (cenotah), ki so neposredno povezane s kraško podtalnico. Razvoj in obstoj starih naselbin Majev, vključno $\mathrm{z}$ mestom Xuenkal, povezujemo $\mathrm{z}$ bližino kraških depresij. $\mathrm{V}$ primeru mesta Xuenkal, so dna vrtač , ki jih lokalno imenujejo rejolladas, nad nivojem podzemne vode in ne nudijo neposrednega dostopa do vode. Ker je bila prisotnost teh vrtač za Maje očitno pomembna, smo izvedli študijo teh objektov s posebnim ozirom na kamninsko podlago in prst. Podatki georadarja (GPR) in poskusnih izkopov, so pokazali veliko debelino prsti v dnu vrtač. Kaže, da je prst najdebelejša v manjših, a globokih vrtačah. Xuenkal je zgrajen sredi goste mreže vrtač, kar je bilo verjetno pomembno pri umestitvi mesta. Maji so očitno s pridom izkoriščali prisotnost vrtač z debelim slojem prsti, kjer se je lahko obdržal gost in zdrav vegetacijski pokrov.

Ključne besede: vrtače (rejollada), arheologija, satelitsko snemanje, georadar

\footnotetext{
${ }^{1}$ Department of Geography, Kent State University, Kent OH, 44242, e-mail: mmunrost@kent.edu

${ }^{2}$ Department of Anthropology, Kent State University, Kent OH, 44242, e-mail: tmanahan@kent.edu

Received/Prejeto: 15.10 .2009
} 


\section{INTRODUCTION}

The northern plains of the Yucatán peninsula (Fig. 1) are dominated by a harsh, semi-arid karst plateau that is largely devoid of both thick soils and surface water, thus making modern and ancient landscape adaptation and agricultural practices particularly challenging. In this landscape are rejolladas, distinctive sinkholes that are usually round and shallow, are typified by bases that sit above the regional water table, and tend to have thicker soils than the surrounding areas (e.g. Kepecs \& Boucher 1996; Fedick \& Morrison 2004; Lopez 2008). The distribution of these sinkholes is particularly dense at the ancient Maya center of Xuenkal, lending support to the argument that rejolladas were likely important to ancient populations. The Proyecto Arqueologico Xuenkal (PAX) was initiated in 2004 to investigate the relationship between Xuenkal and the Terminal Classic (A.D. 900 - 1100) Maya center of Chichen Itza and to understand the political and economic underpinnings of the Terminal Classic transformation. Xuenkal is the largest urban center between Chichen Itza and the coast and a major component of PAX is to investigate the use of rejolladas by the ancient inhabitants of the region. Rejolladas as landforms, however, are poorly understood both in terms of their overall characteristics and their specific genesis. As such, this paper reports the results of non-invasive ground penetrating radar strategies to terrains typically not conducive to intensive methods.

As well as a harsh physical environment, the climate in Yucatán is also relatively harsh with a long dry season dominated by subtropical high pressure, punctuated by a short wet season between July and October when moisture laden air masses from the Gulf of Mexico are forced to move ashore bringing large volumes of rain in a short period of time. Modern precipitation averages about $1,100 \mathrm{~mm}$ a year (SARH 1989), with the majority falling in the wet season. Due to the local geology and climate, the natural vegetation is thorny tropical scrub forest, an environment that should provide major environmental challenges to supporting human populations. Despite all these limitations, large urbanized Maya centers flourished across the Yucatán Peninsula for hundreds of years. In fact, the region in and around Xuenkal and the nearby colonial city of Espita has always been a breadbasket of the Yucatán, supplying corn, beans, and cotton since the $16^{\text {th }}$ century (Andrews 1990; Patch 1993). Archaeological investigations at Xuenkal, Yucatán, Mexico, have demonstrated that ancient residential settlement tends to cluster around, or near, rejolladas, suggesting that the utilization of these natural features has a long history. The unique karst geology and geomorphology of the
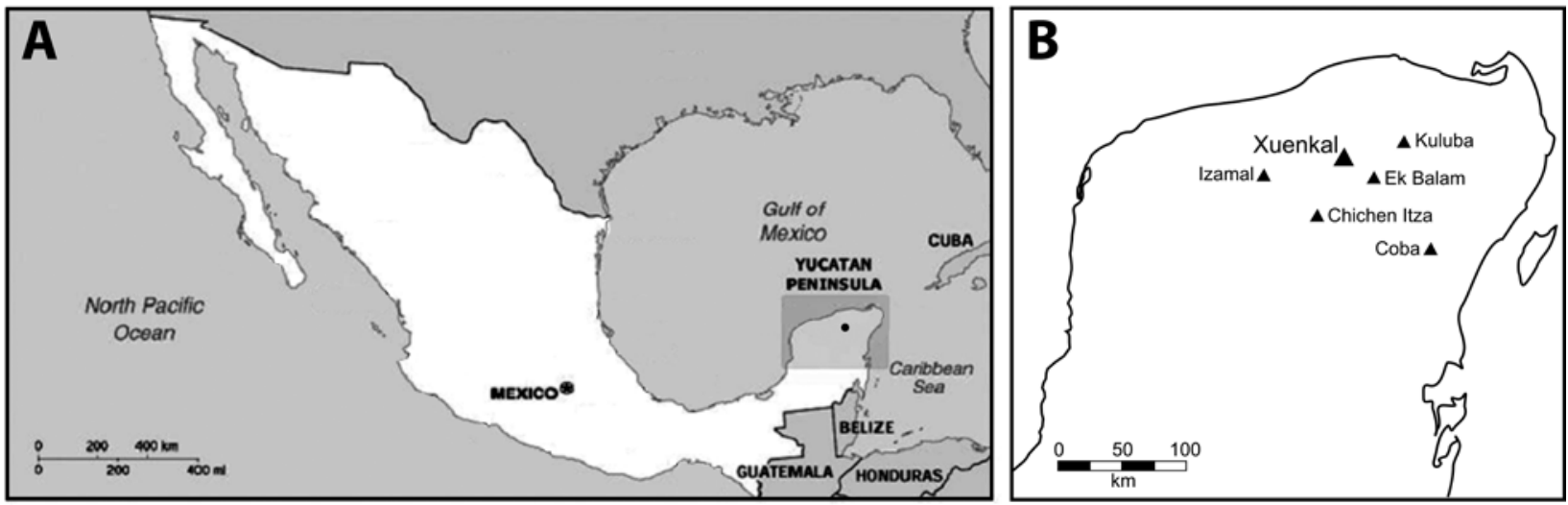

Fig. 1: A. Location of the Yucatán Peninsula in Mexico; B. Location of Xuenkal relative to contemporary pre-Columbian sites.

(GPR) surveys of 3 rejolladas in Xuenkal. Specifically, bedrock configuration, and soil and sediment characteristics are documented. GPR was chosen as the tool of study as it is a well documented non-invasive geophysical method for imaging natural geologic materials or archaeological features near the ground surface (e.g. Leckebusch 2003; Froese et al. 2005). This geomorphic study has broader relevance to understanding how past and present populations have adapted their cultivation region, specifically that of rejolladas, likely held greater agricultural potential, and as such may have drawn ancient settlers to the study area. 


\section{GEOLOGY AND GEOMORPHOLOGY OF THE NORTHERN YUCATÁN PENINSULA}

The Ticul Fault crosses the Yucatán Peninsula trending roughly WNW to ESE separating two very different terrains (Fig. 2): the Sierrita de Ticul sitting approximately $150 \mathrm{~m}$ above sea level (asl) to the south of the fault; and the lower karstic plains sitting to the north at no greater than $40 \mathrm{~m}$ asl (Gonzáles-Herrara et al. 2002). The entire region is composed of thick deposits of uplifted Tertiary limestone bounded by a thin band of Quaternary lagoon and beach deposits at the coast (Pope et al. 1993). Because of the dominance of limestone, groundwater flow is through dissolution fractures, channels, and caverns, rather than above ground (e.g. Springfield \& LeGrand 1976; Gordon 1986). As a result, in the plains the water table sits at between 1 and $4 \mathrm{~m}$ above sea level (Weidie 1985; González-Herrera et al. 2002), i.e., no more than $36 \mathrm{~m}$ below the modern land surface, making karstification a prominent ongoing process near the ground surface in the modern environment. dzonot, Hall 1935) which have collapsed below the level of the water table and thus have year-round standing water. Technically, an underground cavern with standing water but with an opening to the atmosphere is also considered a cenote. Cenotes can be the product of surface collapses, subsurface solution, or a combination of the two processes (Lopez 2008). The Yucatec Maya term $d z a d z$ (plural $d z a d z o b$ ) refers to surface collapses that touch the water table but do not significantly penetrate it. They are typically dominated by small swampy areas in their bases. Depending on the depth of the $d z a d z$ and the amount of silting, some $d z a d z o b$ may be seasonally transformed into wetlands. Finally, rejolladas are surface collapses that do not reach the water table and remain dry throughout the year. The study region in and around Xuenkal contains some cenotes and dzadzob, but rejolladas are by far the most common category of sinkhole (Fig. 3). They also tend to line up following the local joint pattern (Fig. 3). The rejollada density is also significantly higher centered on Xuenkal than in the surrounding terrain (Fig. 4).

Also present are fairly large dissolution hollows and channels (grikes and poljes; cf. Ford \& Williams 2007) that are at the ground surface and are entirely unrelated to collapse. These remain less well understood but they are now filled with calcareous red soils (Terra Rossas) typical of limestone areas dominated by tropical climates (Isphording 1976). Although none of these were investigated in this study, they can clearly be seen on the satellite image presented in Fig. 5 especially where vegetation has been cleared.

Interestingly, on the northern plains thick carbonate deposits overlie the Chicxulub impact crater which is believed to have formed by an asteroid impact at the K$\mathrm{T}$ (Cretaceous/Tertiary) boundary resulting in the mass extinction that took place at the end of the Cretaceous period (Hildebrandt et al. 1991; Pope et al. 1991; 1993). This crater appears to have had an enormous influence on both the location and formation of sinkholes. Verification of the presence of the buried crater comes from 


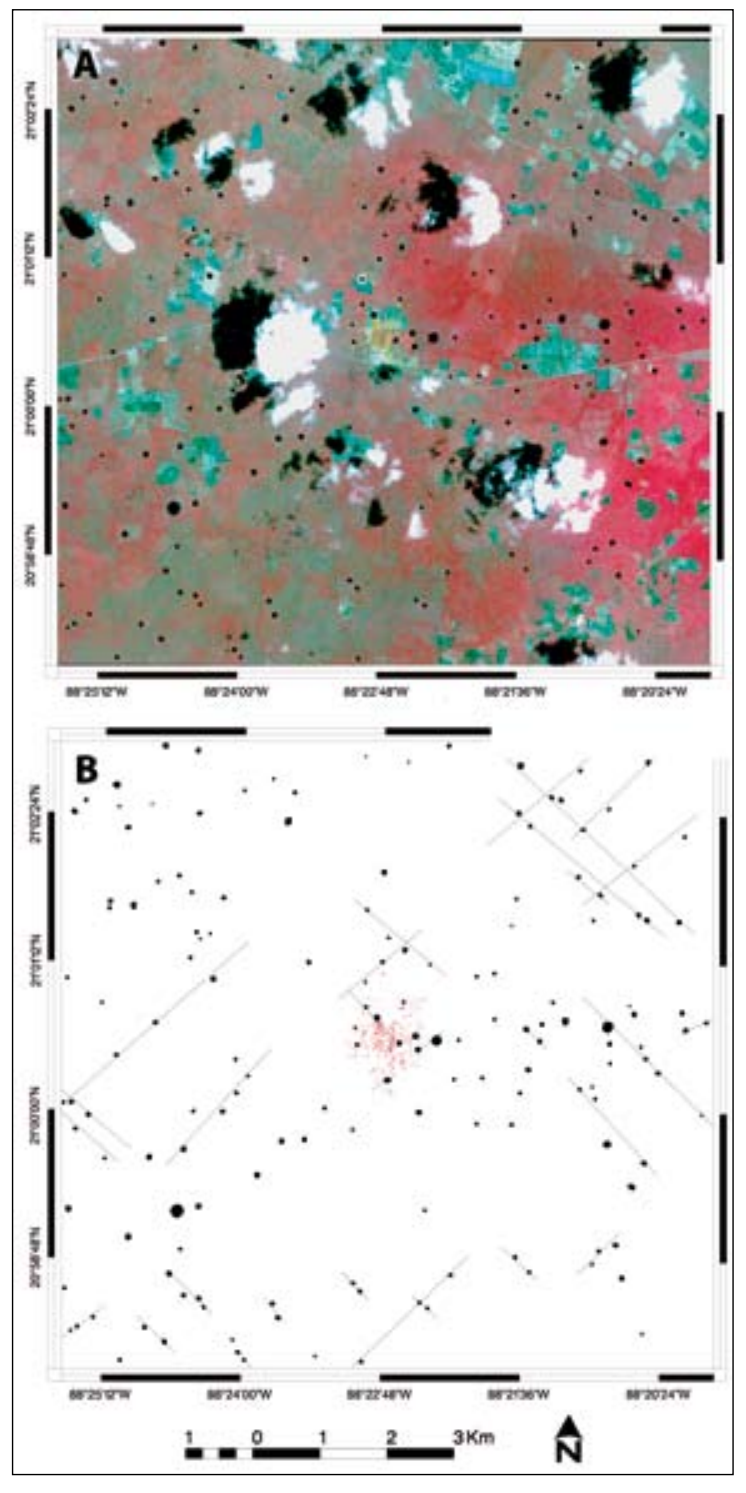

gravity and magnetic anomalies, breccias that show evidence of shock metamorphism and high iridium content (Hildebrandt et al. 1991) and surficially, from the presence of the wellknown Ring of Cenotes (Pope et al. 1991; 1993), a semi-circular ring of sinkholes that lies at or near the edge of the crater (Fig. 2). Here, the abrupt thinning of the limestone relative to the thicker beds in the center of the crater increased bedrock fracturing resulting in higher dissolution and collapse rates in the region of the Ring of Cenotes (Pope et al. 1993). There is debate as to whether the cenotes represent the edge of the impact (Pope et al. 1991; 1993) or the crater rim (Hildebrandt et al. 1991). This interpretation is important as it affects the overall size of the crater, which is estimated to range in diameter from $180 \mathrm{~km}$ (Hildebrandt et al. 1991) to $240 \mathrm{~km}$ (Pope et al. 1993). The study area in and around Xuenkal is dominated by the pervasively fractured Northern Pitted Karst Plain (Lesser \& Weidie 1988; Fig. 2) and lies about $30 \mathrm{~km}$ immediately outside the Ring of Cenotes. While inside the ring there is a lack of significant sinkhole development, outside the ring, especially in the eastern Yucatán, cenotes and other sinkhole types dominate the landscape (Pope et al. 1991). Based on Pope et al's (1991) research, the sinkholes in and around Xuenkal may still represent part of the rim of the Chicxulub impact crater.

Fig. 3: A. False color infrared Quickbird satellite image of a $10 \times 10 \mathrm{~km}$ region centered on Xuenkal (structures shown in yellow). Rejolladas are mapped in black. B. Map of study area showing only rejollada distribution with superimposed trends of rejolladas associated with the regional joint system.

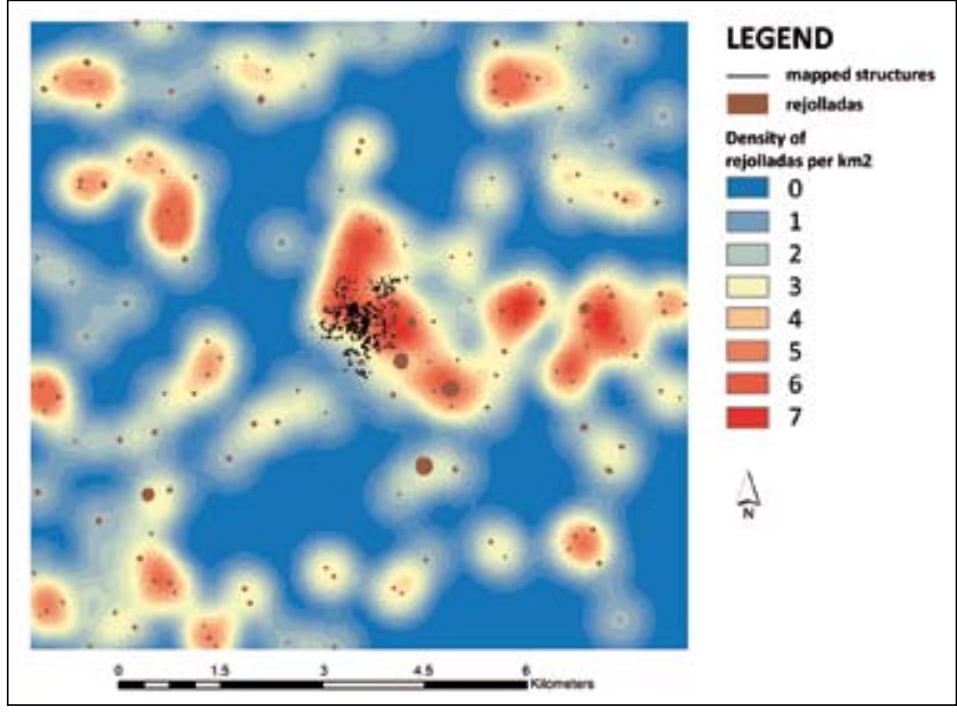

Fig. 4: Map showing the density distribution of rejolladas centered on Xuenkal. Structures are shown in the center of the map and the densest distribution of rejolladas coincides with the position of Xuenkal. 


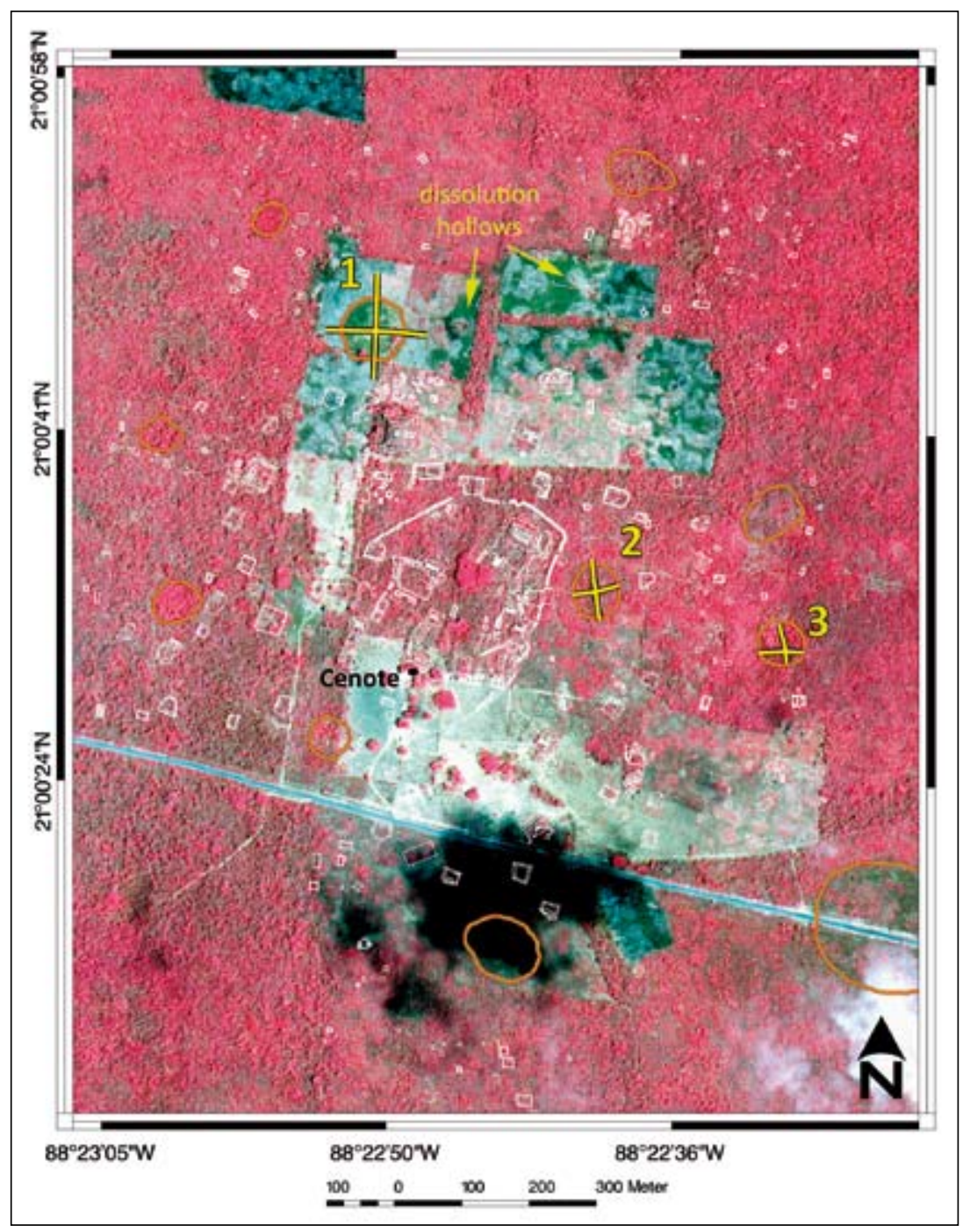

Fig. 5: True color Quickbird satellite image of the terrain in the urban core of Xuenkal. Superimposed are the mapped structures (in white) and rejolladas (in yellow). Studied rejolladas are numbered and transects are shown as intersecting lines.

\section{THE SIGNIFICANCE OF KARST TERRAIN TO THE ANCIENT MAYA}

Archaeologists have documented a rich history of indigenous settlement that spanned from the Middle Preclassic (c.a. 1200 B.C.) through the time of Spanish contact (A.D. 1519). The populations of the Yucatán Peninsula likely reached their peak during the Terminal Classic period (A.D. 900 - 1000) when many expansive ancient Maya centers reached their maximum settlement density. This includes the site of Xuenkal, the center of the present study area, and its famous neighbor, the site of Chichén Itzá located $45 \mathrm{~km}$ to the southwest (Fig. 1). The unique karst geology and geomorphology of the region likely served as a primary factor in guiding initial settlement across the Yucatán Peninsula since ancient Maya centers cluster near sinkholes and depressions. Rejolladas in particular act as traps for soil and moisture producing patches of ground useful for cultivating more water-sensitive crops including groves of trees such as cacao, whose fruit (chocolate) was highly valued in ancient times (e.g., Kepecs \& Boucher 1996). Deep rejolladas were likely important natural features to the ancient Maya because of their proximity to the water table thus they present an ideal location for digging wells in a landscape devoid of above-ground sources of water.

Researchers have long recognized that limited access to groundwater meant that ancient Maya settlement in northern Yucatán clustered around sinkholes of various types. Cenotes were considered as sacred portals that allowed communication with deities associated with rain 
and fertility (Morley 1946). The most famous cenote is the giant Cenote Sagrado (Sacred Well of Sacrifice) at the site of Chichén Itzá, measuring $60 \mathrm{~m}$ in diameter and $27 \mathrm{~m}$ deep to the water surface. The retrieval of thousands of artifacts as well as bones of young men and boys appears to support the use of the cenote as a place to leave offerings to the gods (Tozzer 1957; Proskouriakoff 1974).

In the Yalahau region in the far northeast of the Yucatán Peninsula, Fedick and Morrison (2004) noted that all elite residential centers, or sites with monumental architecture, are associated with large sinkholes (in the form of either cenotes or $d z a d z o b$ ) whereas non-elite sites were associated with smaller cenotes with surface openings often less than about $4 \mathrm{~m}$ in diameter.

Special attention has been paid to rejolladas as it is generally thought that they were controlled during the Classic period (A.D. 600-900) by local elites who grew orchards of economically useful trees, especially cacao, the most valuable pre-Columbian crop (Kepecs \& Boucher 1996). For instance, the frieze adorning an elite compound in Chichén Itzá depicts cacao growing in rejollada-like depressions accompanied by elites dancing with monkeys in the groves. Gómez-Pompa et al. (1990) suggested that the microclimates of rejolladas and cenotes allowed for prehispanic cacao cultivation and production and for consumption by local elites after identifying rare remnant sub-species of cacao (Theobroma cacao) that were descendants from prehispanic species in three cenotes near Valladolid, $50 \mathrm{~km}$ south of Xuenkal. An inventory of modern plant species was undertaken in 21 rejolladas and 3 cenotes in an $8 \mathrm{~km}$ area surrounding Xuenkal (Triplett et al. 2006) on the assumption that some would possess non-modified habitats, with a heavy presence of only native species including feral populations of cacao. This was not the case. Many rejolladas are currently heavily planted and contain important fruit crops such as avocado (Perseas Americana), mango, nance (Byrsonima crassifolia), caimito (Chrysophyllum caimito), and sapodilla (Manilkara zapota), and are clearly evidence of long-standing cultivation.

\section{THE SITE OF XUENKAL}

Xuenkal was first recorded in the late 1970s as a Rank II category site in the classification system determined by the Atlas Arqueológico del Estado de Yucatán and is considered to be an urban center (Garza \& Basco 1980). The area in and around Xuenkal contains a dense pattern of rejolladas (Fig. 4), with the currently mapped $1.2 \mathrm{~km}^{2}$ area of site core containing 8 rejolladas and one small cenote which is a subterranean cavern with a small opening to the ground surface (Fig. 5). The site contains monumental architecture including a series of large pyramidal temples, a large palace structure, a major defensive wall system, and elite and non-elite residential groups. Many of these, especially residential structures, cluster around the rejolladas. Of note, the largest pyramid looms over Rejollada 1, and the palace structure tops a bedrock rise on the western edge of Rejollada 2 (Fig. 5).

Average elevations of the karst surface at Xuenkal vary between 26 and $28 \mathrm{~m}$ asl with rejollada bases below this level as low as $10 \mathrm{~m}$ asl (Tab. 1). Bare limestone sur- face covers much of the area, with pockets of Terra Rosa filling surface hollows. Most ancient Maya structures are built on the bare limestone surfaces. Based on the water level in the cenote and in a modern well, the water table appears to sit at about 4-6 m asl. This is about $6 \mathrm{~m}$ higher than suggested by Lesser and Weidie (1988) and González-Herrera et al. (2002) for the region, and about $6 \mathrm{~m}$ below the depth of the deepest rejollada studied.

Tab. 1: Average statistics of the three studied rejolladas.

\begin{tabular}{|l|c|c|l|l|}
\hline & $\begin{array}{l}\text { Average } \\
\text { basal } \\
\text { diameter }\end{array}$ & Depth & $\begin{array}{l}\text { Base } \\
\text { elevation } \\
\text { above sea } \\
\text { level }\end{array}$ & $\begin{array}{l}\text { Average } \\
\text { slope } \\
\text { angle }\end{array}$ \\
\hline Rejollada 1 & $97 \mathrm{~m}$ & $4 \mathrm{~m}$ & $22 \mathrm{~m}$ & $9.25^{\circ}$ \\
\hline Rejollada 2 & $68 \mathrm{~m}$ & $8 \mathrm{~m}$ & $18 \mathrm{~m}$ & $14.8^{\circ}$ \\
\hline Rejollada 3 & $58 \mathrm{~m}$ & $12 \mathrm{~m}$ & $10 \mathrm{~m}$ & $25.3^{\circ}$ \\
\hline
\end{tabular}

\section{GPR DATA AND METHODS}

Since the main purpose of this research was to determine the overall configuration of the rejolladas, a necessary analytical technique was required to image the subsurface rocks and sediment. One of the most common shallow geophysical techniques used is seismic reflection and refraction, however the resolution is too coarse to look at submeter resolution 


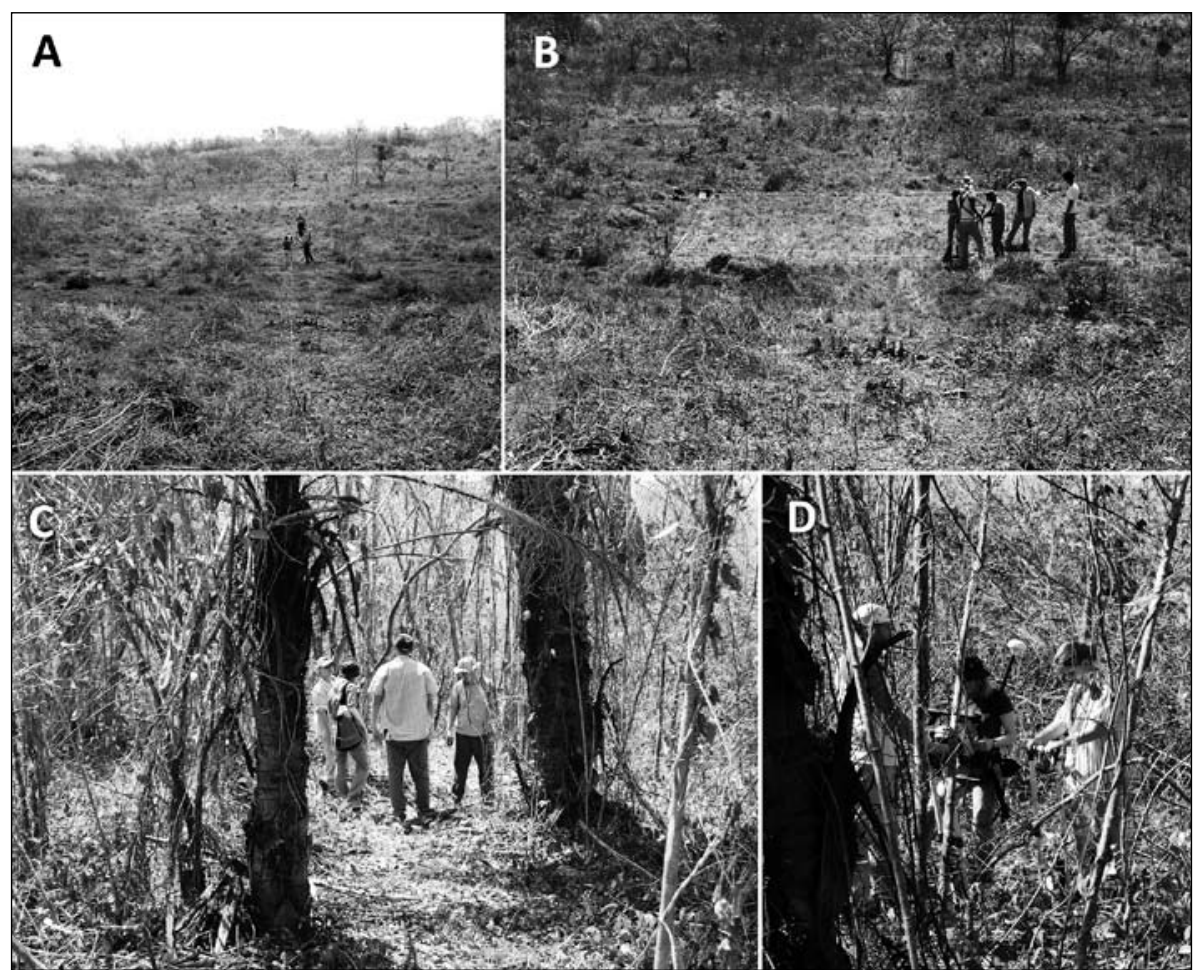

Fig. 6: Photographs of the rejolladas where GPR work was undertaken. A. running a transect across rejollada 1. Note there are no trees, simply pasture; B. Collecting GPR grid data in rejollada 1; C. Collecting a GPR transect in Rejollada 2. Note that there is significant tree cover; $D$. Collecting a GPR transect in rejollada 3. Note that the vegetation is very dense here (Photo: $M$. Munro-Stasiuk).

layers (Neal 2004) which is required for this study. Consequently, we chose ground penetrating radar (GPR) which is also a non-invasive geophysical method for imaging natural geologic materials or archaeological features near the ground surface (e.g. Jol \& Bristow 2003; Leckebusch 2003; Froese et al. 2005). This technique is particularly good at imaging limestone (Jol \& Bristow 2003). Pulses of high frequency electromagnetic radiation are transmitted into the ground and are absorbed, reflected or attenuated by the subsurface materials. A receiver records the amount, and strength, of the reflected waves, which vary based on sediment and bedrock type, grain size, porosity and compaction (dielectric properties; Jol \& Bristow 2003).

The system used for this study was a PulseEkko Pro GPR with interchangeable $100 \mathrm{MHz}$ and $200 \mathrm{MHz}$ anten- nae. All data were captured in reflection mode using a step size of $25 \mathrm{~cm}$ for the 100 $\mathrm{MHz}$ antennae and $10 \mathrm{~cm}$ for the $200 \mathrm{MHz}$ antennae. Since radar waves move through different materials at different speeds (because of different dielectric properties), all data were calibrated to an average wave velocity of $0.099 \mathrm{~m} / \mathrm{ns}$ for soil and sediment, and 0.112 $\mathrm{m} / \mathrm{ns}$ for limestone. Velocities were determined by fitting a hyperbola-response curve to the GPR data. All data have a permanent dewow filter applied, which removes unwanted low frequency interference. In addition an AGC (Automatic Gain Control) was applied to the dataset, which deliberately enhances weak signals at depth (Sensors and Software 2003). All data were georeferenced, topographically corrected, and analyzed in EkkoView, EkkoView Deluxe, EkkoMapper and Voxler 3D.

A 2-phase GPR survey was completed. Phase 1 was a general 2-dimensional overview of each of the three rejolladas at Xuenkal (Figs. 5 and 6). This consisted of a 2-line $100 \mathrm{MHz}$ survey, and a 2-line $200 \mathrm{MHz}$ survey (Tab. 2), each consisting of an approximate east-west transect and a north-south transect that cross each other in the approximate center of each of the rejolladas (Fig. 5). Phase 2 consisted of grid surveys, which have a series of $\mathrm{x}$-lines and $\mathrm{y}$-lines that cross each other, allowing 3-D data interpolation and interpretation. This was only completed on Rejollada 1 . Grid surveys were conducted with the higher resolution $200 \mathrm{MHz}$ antennae only, which provides higher resolution data, although the depth of radar penetration is compromised. A standard WAAS enabled handheld GPS was used to tag the ends of every line and the corners of every grid. In addition, GPS integrated with the GPR data collection ensured that all data were tied to the geographic grid. Elevation was derived with a TopCon GTS-226 Total Station and recorded with a Ranger N687 data collector.

Tab. 2: GPR survey parameters.
\begin{tabular}{|l|c|c|c|c|}
\hline SURVEY TYPE & $\begin{array}{l}\text { Antennae } \\
\text { separation }\end{array}$ & $\begin{array}{l}\text { Step size (how far antennae } \\
\text { are moved between data } \\
\text { points) }\end{array}$ & $\begin{array}{l}\text { Grid line } \\
\text { spacing }\end{array}$ & $\begin{array}{l}\text { Approximate } \\
\text { maximum depth }\end{array}$ \\
\hline $100 \mathrm{MHz}$ lines & $1 \mathrm{~m}$ & $25 \mathrm{~cm}$ & NA & $6.5 \mathrm{~m}$ \\
\hline $200 \mathrm{MHz}$ lines & $50 \mathrm{~cm}$ & $10 \mathrm{~cm}$ & NA & $3.25 \mathrm{~m}$ \\
\hline $200 \mathrm{MHz}$ grids & $50 \mathrm{~cm}$ & $10 \mathrm{~cm}$ & $50 \mathrm{~cm}$ & $3.25 \mathrm{~m}$ \\
\hline
\end{tabular}




\section{GPR PROFILING}

The GPR reflectance patterns in all three rejolladas show there to be marginal slopes dominated by bedrock at the surface, some sediment and soil in the rejollada bases that mutes the overall signal, evidence of potential man-made structures, and a lack of any distinct GPR reflectors that would indicate the presence of the water table. In terms of the bedrock configuration, all three rejolladas represent bedrock ceiling collapse sinkholes. Although the style of collapse may have varied slightly from sinkhole to sinkhole, they all collapsed into underlying caverns.

\section{REJOLLADA 1}

In Rejollada 1, there are distinct GPR reflectors along the slopes of the rejollada and along the base. These are higher amplitude reflectors associated with limestone beds. The reflectance pattern along the walls shows slight slumping and disturbance of the bedrock. Importantly, there is significant reflectance from an uneven distribution of relatively high conductivity material bound laterally by pockets of lower conductivity material. This is interpreted as soil and sediment overlying an uneven distribution of limestone rubble. The limestone rubble is from a ceiling collapse onto an underlying cavern floor (Figs. 7 and 8). A very prominent feature on the GPR profiles of Rejollada 1 shows a zone of comparatively deeper low conductivity (few reflectors) soil/sediment bounded laterally by the more variable conductivity materials (limestone rubble). No sign of the rubble exists in this zone, which is interpreted as a solution sinkhole, at least $9 \times 18 \mathrm{~m}$ in size, which has subsequently filled with lower conductivity sediment and soil. The solution hole formed prior to the bedrock collapse when water was still partially flowing at the ground surface. Subsequent infilling represented by undisturbed horizontal layers of sediment and soil attests to collapse followed by soil development. It is even possible that this may have been a small cenote connecting to the underground water source but this is difficult to confirm without excavation.

\section{REJOLLADA 2}

Rejollada 2 is bound by undisturbed rock walls that appear to have intact bedding (Fig. 9). This rejollada represents a major collapse sinkhole into an underlying cavern that left the adjacent bedrock layers untouched. The collapse zone is bounded by steep normal faults. Soil and sediment accumulation seems significant based on very low conductivity reflectors observed on all GPR transects across the bottom of the rejollada.

A $2 \times 2 \mathrm{~m}$ test excavation was placed in the center of Rejollada 2 (Fig. 10). With the exception of a low historic wall approximately $20 \mathrm{~m}$ north of the test pit, no prehis- toric remains are visible on the surface of the rejollada. The excavation was conducted in arbitrary $20 \mathrm{~cm}$ levels and reached a total depth of $228 \mathrm{~cm}$, much deeper than any other test pits excavated at Xuenkal. The excavation uncovered three distinct stratigraphic zones although all soil tended towards reddish silt loam with high clay content. Stratigraphic variation consisted principally of changes in soil moisture, compaction, color intensity, and organic content. Generally, soil becomes redder, drier, more compact, and contains decreasing quantities of organic matter with depth. A very thin surface O-horizon (organic layer) exists in the soil profile and grades quickly to a $20-30 \mathrm{~cm}$ moist dark red/brown clay silt loam (2.5 YR 2.5/2) representing the A-horizon (the uppermost organic layer below the O-horizon with the greatest amount of biological activity). The A-horizon brightens with depth grading to a semi-moist dark red/ brown clay silt loam (2.5 YR 3/6) that reaches a depth of $90-100 \mathrm{~cm}$ below surface. A heavily leached, B-horizon of dry, bright red clay silt loam (2.5 YR 4/8) extends to bedrock which has a very uneven, undulating surface and a bright white color at a depth of between 220 and $228 \mathrm{~cm}$. Five flotation samples and five microfloral samples were collected from the unit's profile column. Flotation samples failed to identify any macrobotanical remains. This soil is typical of the Terra Rossas (also locally known as Kancab) found throughout the region (Isphording 1976; Allen \& Rincón 2003).

\section{REJOLLADA 3}

Like Rejollada 2, this rejollada is bound by undisturbed rock walls with intact bedding (Fig. 11). Once again, this represents a major collapse sinkhole into an underlying cavern that left the adjacent bedrock layers untouched. Soil development seems significant based on very low conductivity reflectors observed on all GPR transects across the bottom of the rejollada. While no test pit was dug here, soil was likely as thick as at Rejollada 2 based on the homogeneity of the GPR signal in the bottom of the rejollada. Several anomalies that were detected in the transects may be anthropogenic in origin. Many of these have the characteristics of walls (cf. Conyers 2004) or stone-lined wells. These need to be ground-checked before further interpretation can be made, however archaeological investigations of other rejolladas in northern Yucatán have identified ancient constructions including walls and stone-lined wells (González de la Mata 2006; Houck 2006). 

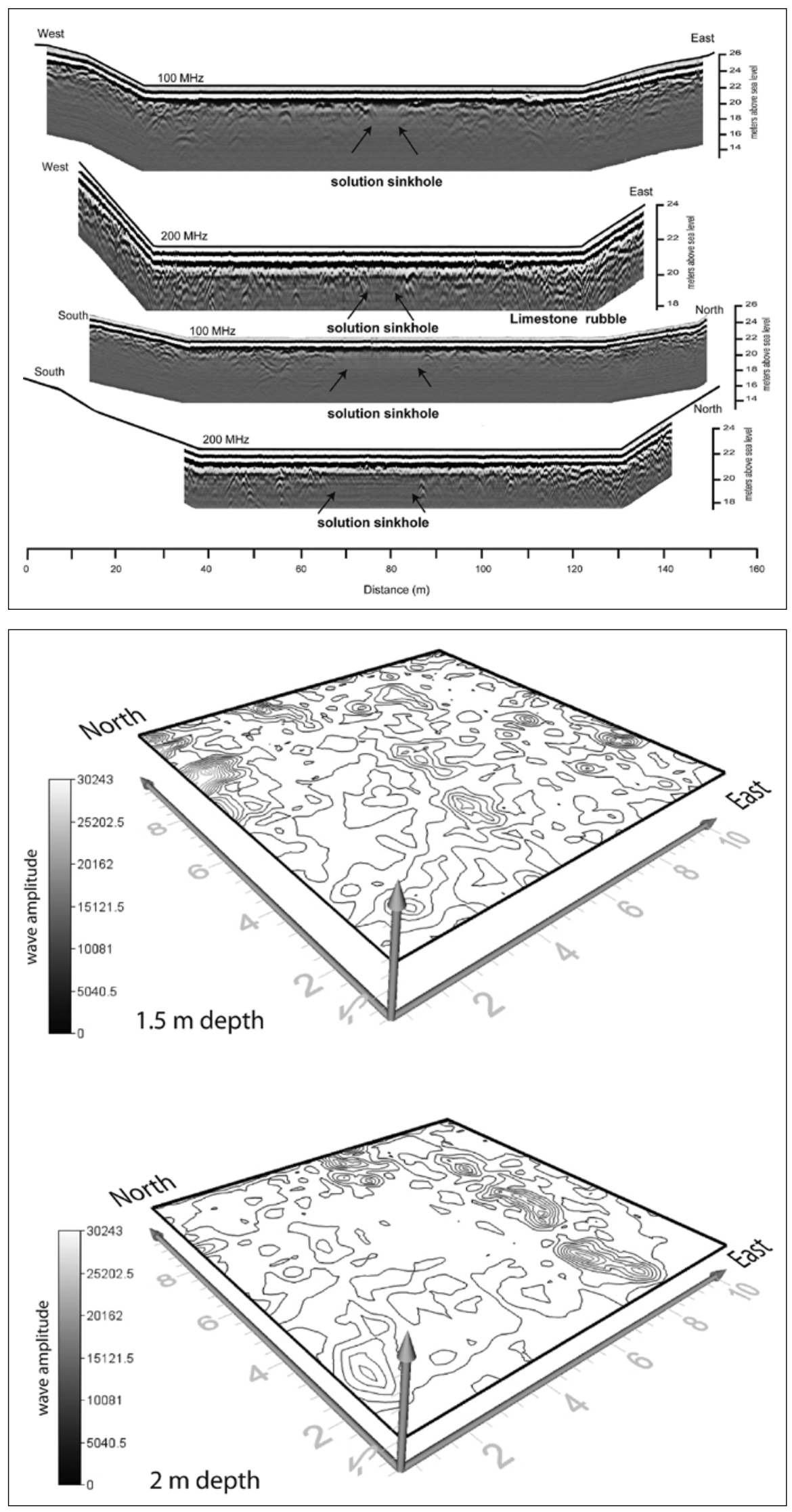

Fig. 7: GPR cross-sections of Rejollada 1 with interpretations.
Fig. 8: Contour rendering of grid at Rejollada 1 showing slices at $1.5 \mathrm{~m}$ below ground level and $2 \mathrm{~m}$ below ground level. The limestone rubble can easily be seen on both plots as contours of higher amplitude reflectors. 

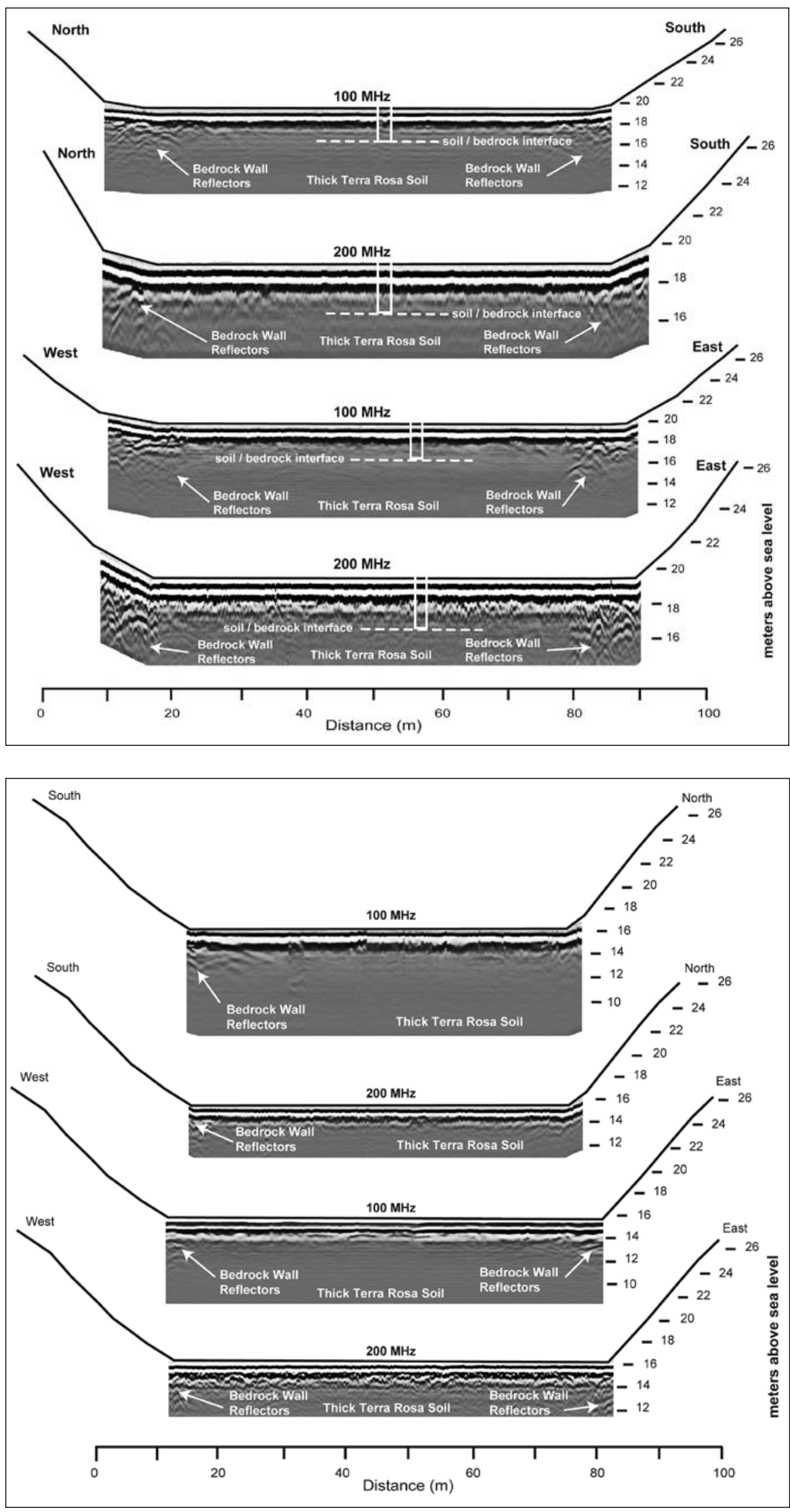

Fig. 9: GPR transects at Rejollada 2. Very steep contacts with the bedrock walls suggest the presence of major faults. The position of the soil pit is shown on each of the transects.
Fig. 11: GPR transects at Rejollada 3. Steep contacts with the bedrock walls (especially on the west-east transects) suggest the presence of major faults. 


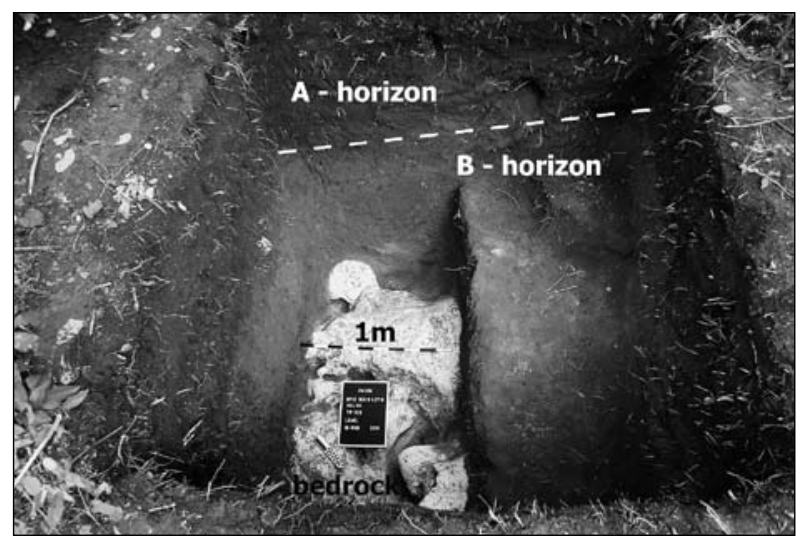

Fig. 10: Photograph of $2 \times 2 \mathrm{~m}$ soil pit in the center of Rejollada 2 (Photo. K. Manahan).

\section{DISCUSSION}

The GPR survey confirms that soil depths in the bottom of the rejolladas average over $1 \mathrm{~m}$, and in rejolladas 2 and 3 , over $2 \mathrm{~m}$. This was confirmed by the test pit excavation in rejollada 2 . The significance of this finding is enhanced when one considers that, on average, soils in the region outside of rejolladas seldom exceed $60 \mathrm{~cm}$ in depth over hollows and a few centimeters in depth over the rest of the terrain. In addition, the overall configuration of the rejolladas may help to predict where the thickest soils accumulate. Rejollada 1, though the largest, has the thinnest soil/sediment package; rejolladas 2 and 3, though smaller have thicker soils. This is most likely related to the overall relief. Deeper, steeper rejolladas, like 2 and 3, generally have more rainwater that washes down the slopes increasing the overall rate of dissolution (Weisbach et al. 2001). The Terra Rossa forms due to the presence of limestone. That is, carbonated waters - the result of dissolution - tend to break down clays and remove silica. Hence soils become depleted in both carbonates and silicates and become preferentially enriched in other minerals, in this case kaolinite, chlorite, boehmite, quartz, and talc (Isphording 1976) as well as aluminum and iron (Weisbach et al. 2001). The iron rusts when exposed to the atmosphere creating the characteristic red color. It appears that where there is greater relief, and hence also greater washing across the surface by rainwaters, there are more favorable conditions to develop soils of the Terra Rossa variety.

In addition, the deepest rejolladas have bases closest to the water table. The GPR work proved very useful in determining overall rejollada configuration and presence of thick soils, but it unfortunately did not identify the water table. Al-fares et al. (2002) in a study in French karst, used the same PulseEkko Pro GPR system with lower frequency $50 \mathrm{MHz}$ antennae and achieved penetration of up to $30 \mathrm{~m}$ and clearly identified the water table. Thus there is great potential for identifying this horizon at Xuenkal using lower frequency antennae in future surveys. Based on the wave velocity through the materials at Xuenkal, $50 \mathrm{MHz}$ antennae should penetrate up to $20 \mathrm{~m}$ below the surface, which should map the water table effectively in this environment. Other methods such as electrical resistivity could also better identify the water table (cf. Urish 1983). Even though we were unable to identify the depth and configuration of the water table, evidence from wells in the area suggests that the bottom of the deepest rejolladas sits within approximately $6 \mathrm{~m}$ of the water table.

\section{CONCLUSION}

The deeper soils of the rejolladas, together with their closer proximity to the water table, would have presented clear advantages to ancient farmers whose subsistence depended upon adequate seasonal rainfall. Extensive exploitation of the rejolladas with their significantly thicker soils and greater proximity to the water table, may have been one strategy employed by the ancient Maya. We hope to investigate this possibility in more detail in the future; the GPR study of the rejolladas represents the first step in this direction. 


\section{ACKNOWLEDGEMENTS}

Help in the field is gratefully acknowledged from Justin Lowry, Daniel Vallejo Caliz, Leonard Drinkard, Jessica Sudduth, and Jana Reeder. Comments from reviewers
Ivan Šprajc and Branko Mušič helped to improve the content of this paper.

\section{REFERENCES}

Al-fares, W., Bakalowicz, M., Guérin, R. \& M. Dukhan, 2002: Analysis of the karst aquifer structure of the Lamalou area (Hérault, France) with ground penetrating radar.- Journal of Applied Geophysics, 51, 97-10.

Allen, M.F. \& E. Rincón, 2003: The changing global environment and the Lowland Maya: past patterns and current dynamics.- In: Gomez-Pompa, A. et al. (eds.) The Lowland Maya Area: Three Millenia at the Human-Wildland Interface. Food Products Press, pp. 13-30, Riverside.

Andrews, A.P., 1990: The Fall of Chichén Itzá: A Preliminary Hypothesis.- Latin American Antiquity, 1, 258-267.

Conyers, L.B., 2004: Ground-penetrating radar for Archaeology.- Altamira Press, pp. 203, Walnut Creek, California.

Fedick, S.L. \& B.A. Morrison, 2004: Ancient use and manipulation of landscape in the Yalahau region of the northern Maya lowlands.- Agriculture and Human Values, 21, $207-219$.

Ford, D.C. \& P.W. Williams, 2007: Karst Hydrogeology and Geomorphology.- Wiley, pp. 562, Chichester.

Froese, D.G., Smith, D.G. \& D.T. Clement, 2005: Characterizing large river history with shallow geophysics: Middle Yukon River, Yukon Territory and Alaska.Geomorphology, 67, 391-406.

Garza T. de G.S. \& E.B.K. Basco, 1980: Atlas Arqueológico del Estado de Yucatán.- Instituto Nacional de Antropología e Historia, pp. 249, Mexico City.

Gómez-Pompa, A., Flores, J.S. \& M.A. Fernández, 1990: The Sacred Cacao Groves of the Maya.- Latin American Antiquity, 1, 247-257.

González de la Mata, R., 2006: Agua, agricultura y mitos: El caso de tres rejolladas de Chichen Itza. - In: Laporte, B. \& H.M. Arroyo (eds.) XIX Simposio de Investigaciones Arqueológicas en Guatemala, $18^{\text {th }}-22^{\text {nd }}$ July 2006, Finca la Aurora, Guatamela. Museo Nacional de Arqueología y Etnología, 305-318, Finca la Aurora.
González-Herrera, R., Sánchez-y-Pinto, I. \& J. GamboaVargas, 2002: Groundwater-flow modeling in the Yucatán karstic aquifer, Mexico.- Hydrogeology Journal, 10, 539-552.

Gordon, M.J., 1986: Dependence of effective porosity on fracture continuity in fractured media.- Ground Water, 24, 446-452.

Hall, F.G., 1935: Physical and Chemical Survey of Cenotes of Yucatán, in The Cenotes of Yucatán.- Carnegie Institute of Washington Publication, 457, 5-16.

Hildebrand, A.R., Penfield, G.T., Kring, D.A., Pilkington, M., Camargo, A., Jacobsen, S.B. \& W.V. Boynton, 1991: Chicxulub Crater: A Possible Cretaceous/Tertiary Boundary Impact Crater on the Yucatán Peninsula, Mexico.- Geology, 19, 867-871.

Houck, C. W., 2006: Cenotes, Wetlands, and Hinterland Settlement.- In: Mathews, J. \& B. Morrison (eds.) Lifeways in the Northern Maya Lowlands: New Approaches to Archaeology in the Yucatán Peninsula. University of Arizona Press, pp. 56-76, Tucson.

Ipshording, W.C., 1976: Weathering of Yucatán limestones: the genesis of terra rossas.- In: Ward A. \& W. Weidie (eds.) Carbonate Rocks and Hydrogeology of the Yucatán Peninsula, Mexico. New Orleans Geological Society, pp. 259-274, New Orleans.

Jol, H.M. \& C.S. Bristow, 2003: GPR in sediments: advice on data collection, basic processing and interpretation, a good practice guide.- In: Bristow, C.S. \& H.M. Jol (eds.) Ground Penetrating Radar in Sediments. Geological Society of London Special Publication 211, pp. 9-27, London.

Kepecs, S. \& S. Boucher, 1996: The Pre-Hispanic Cultivation of Rejolladas and Stone Lands: New Evidence from Northeast Yucatán.- In: S. Fedick (ed.) The Managed Mosaic: Ancient Maya Agriculture and Resource Use. University of Utah Press, pp. 69-91, Salt Lake City.

Leckebusch, J., 2003: Ground-penetrating radar: A modern three-dimensional prospection method.- Archaeological Prospection, 10, 213-240. 
Lesser, J.M. \& A.E. Weidie, 1988: Region 25, Yucatán Peninsula.- In: Bak, W. et al. (eds.) Hydrogeology. Geological Society of America, pp. 237-24, Boulder.

López, L.A.M., 2008: Underwater Archaeological Exploration of the Mayan Cenotes.- Museum International, 60, 100-110.

Morley, S.G., 1946: The Ancient Maya.- Stanford University Press, pp. 520, Stanford.

Munro-Stasiuk, M.J. \& T.K. Manahan, 2009: Ground penetrating radar (GPR) analysis of karst environments near the ancient Maya center of Xuenkal, Yucatán, Mexico.- Papers of the Applied Geography Conference, 32, 352-361.

Neal, A., 2004: Ground-penetrating radar and its use in sedimentology: principles, problems and progress.Earth-Science Reviews, 66, 261-330.

Patch, R.W., 1993: Maya and Spaniard in Yucatán 16481812.- Stanford University Press, pp. 329, Stanford.

Pope, K.O., Ocampo, A.C. \& C.E. Duller, 1991: Mexican Site for K/T Impact Crater?- Nature, 351, 105.

Pope, K.O., Ocampo, A.C. \& C.E. Duller, 1993: Surficial geology of the Chicxulub impact crater, Yucatán, Mexico.- Earth, Moon and Planets, 63, 93-104.

Proskouriakoff, T., 1974: Jades from the Cenote of Sacrifice, Chichen Itza, Yucatán.- Harvard University Press, pp. 217, Cambridge.

SARH, 1989: Sinópsis Geohidrológica del Estado de Yucatán [Geohydrologic synopsis of the State of Yucatán]. Secretaría de Agricultura y Recursos Hidráulicos. Subsecretaría de Infraestructura Hidráulica. Dirección General de Administración y Control de Sistemas Hidrológicos, Mexico, DF.
Sensors and Software. 2003: EKKO View Enhanced and EKKO_View Deluxe User Guide.- Sensors and Software Inc. $132 \mathrm{p}$.

Springfield, V.T. \& H.E. LeGrand, 1976: Karst hydrology of Northern Yucatán Peninsula, Mexico.- In: Ward, A. \& W. Weidie (eds.) Carbonate Rocks and Hydrogeology of the Yucatán Peninsula, Mexico. New Orleans Geological Society, pp. 192-210, New Orleans.

Tozzer, A.M., 1957: Chichen Itza and its Cenote of Sacrifice : a comparative study of contemporaneous Maya and Toltec.- Memoirs of the Peabody Museum of Archaeology and Ethnology, Harvard University, pp. 316, Cambridge.

Triplett, K., Gutierrez, C. \& T. Ardren, 2006 : Ethnobotanical Investigations.- In: Manahan T.K. \& T. Ardren (eds.) Report of the 2005 Proyecto Arqueologico Xuenkal Field Season. Foundation for the Advancement of Mesoamerican Studies Inc., pp 25-29, Crystal Springs.

Urish, D.W., 1983: The practical application of surface electrical resistivity to detection of ground-water pollution.- Ground Water, 21, 144-152.

Weidie, A.E., 1985: Geology of Yucatán Platform.- In: Ward, A. et al. (eds.) Geology and Hydrogeology of the Yucatán and Quaternary Geology of Northeastern Yucatán Peninsula. New Orleans Geological Society, pp. 1-19, New Orleans.

Weisbach, C., Tiessena, H. \& J.J. Jimenez-Osorniob, 2001: Soil fertility during shifting cultivation in the tropical Karst soils of Yucatán.- Agronomie, 22, $253-263$. 
